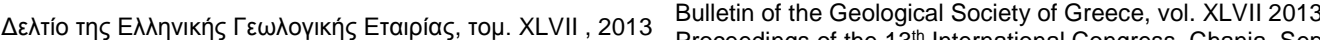

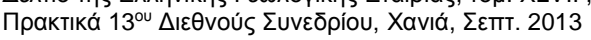
2013

\title{
VARIOUS MORPHOLOGICAL TYPES OF THERMOGENIC TRA VERTINES IN NORTHERN EUBOEA AND EASTERN CENTRAL GREECE
}

\author{
Kanellopoulos C. ${ }^{1}$ \\ ${ }^{1}$ Doctor in Geological Sciences, 15 Pindou str., Vrilissia, Athens, 15235, Greece, \\ ckanellopoulos@gmail.com
}

\begin{abstract}
In the northern part of Euboea Island and the neighbouring part of the mainland in eastern central Greece, many hot springs exist and some of them create travertine deposits. The objectives of the study were to identify and describe the various morphological types of the thermogenic travertine deposits. The samples were studied at the lab with optical microscopy, X-Ray Diffraction, Scanning Electron Microscopy (SEM) and Energy Dispersive Spectroscopy (EDS), in order to verify their main mineralogical composition and their mineral chemistry. The studied travertine deposits consist mainly of aragonite and calcite, but in some cases, as main mineral phase, an amorphous hydrous ferric oxyhydroxide (ferrihydrite), was also identified. The morphological types that were identified were of great variety (mounds, travertine caves etc) and some of them were quite rare (cascades, remora etc). Morphological data and field observations suggest possible inorganic and organic controls on carbonate precipitation. Similar morphological types have been recorded at large travertine systems like Mammoth hot springs, Yellowstone National Park in USA and at Rapolano Terme, Italy.
\end{abstract}

Key words: hot spring deposits, travertine, Edipsos, Ilia, Thermopylae.

\section{Пєрí $\eta \psi \eta$}

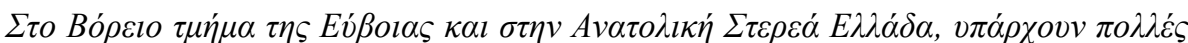

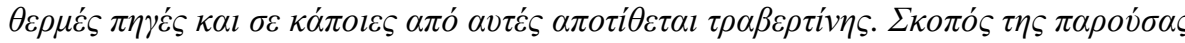

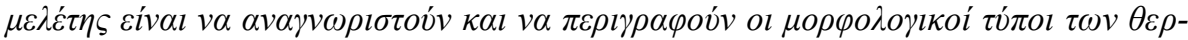

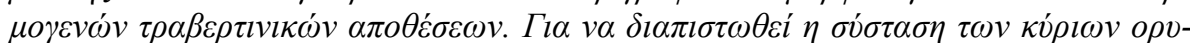

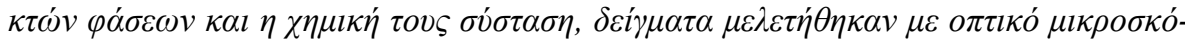

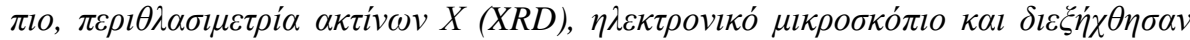

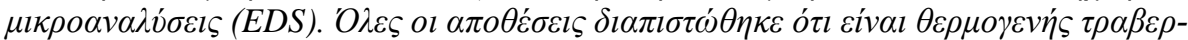

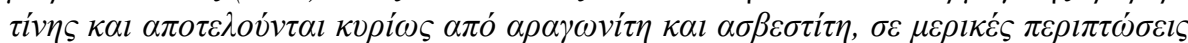

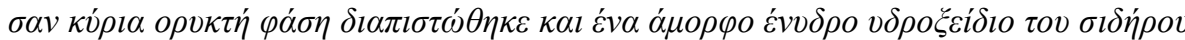

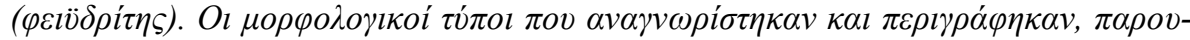

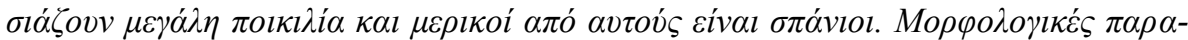

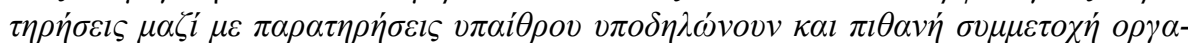

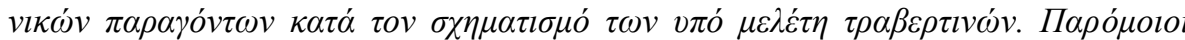

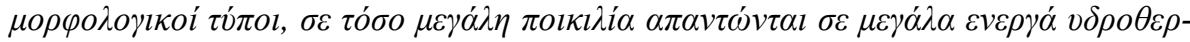

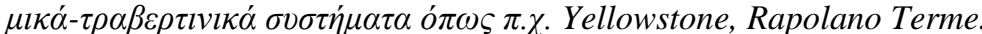

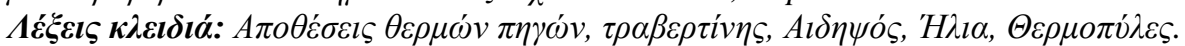

$\underline{\text { XLVII. No } 3-1929}$ 


\section{Introduction}

The word travertine is thought to originate from the lapis tiburtinus, a Roman building stone mentioned by several Latin authors (e.g. Plinius, Statius, Vitruvius). The stone was quarried near the town of Tibur (Tivoli). Various researchers (Whitten and Brooks, 1972; Mitchell, 1985; Bates and Jackson, 1987; Riding, 1991; Koban and Schweigert, 1993; Glover and Roberston, 2003) have proposed many definitions for the term travertine. Perhaps the most comprehensive and clear definition was proposed by Pentecost (2005), who defined travertine as a chemically-precipitated continental limestone formed around seepages, springs and along streams and rivers, occasionally in lakes and consisting of calcite or aragonite, of low to moderate intercrystalline porosity and often high mouldic or framework porosity within a vadose or occasionally shallow phreatic environment. Precipitation results primarily through the transfer (evasion or invasion) of carbon dioxide from or to a groundwater source leading to calcium carbonate supersaturation, with nucleation/crystal growth occurring upon a submerged surface and can take many forms.

Three main criteria have been used for travertine classification: i) geochemical, ii) fabric and iii) morphology. Classification schemes based on these criteria are not mutually exclusive, but it is convenient to consider them separately (Penecost and Viles, 1994). Based on geochemistry two classes of travertines are recognized: a) the meteogene and b) the thermogenic travertines. The second group consists of travertines of hot springs and the carrier $\mathrm{CO}_{2}$ results primarily from the interaction between hot rock and $\mathrm{CO}_{2}$-rich fluids. The term fabric refers to the architecture of the deposit (i.e. the arrangement, density and size of the building units). Density is related to deposit porosity and the nature of the porosity provides valuable clues to the mode of deposition. Bacteria and plants in particular can influence the travertine fabric. Also important is the rate of deposition, the mineralogy, and the extent of diagenesis (Viles and Goudie, 1990).

For the characterization of travertines based on morphological criteria, many classifications have been suggested (Ordonez et al., 1986; Chafetz and Folk, 1984; Scheuer and Schweitzer, 1989). The most recent and probably the most comprehensive classification is proposed by Penecost and Viles (1994). Based on that morphological classification, travertines can be grouped into nine main categories, divided into two sub-groups. The first sub-group contains all of the autochthonous deposits associated with springs, streams, rivers, lakes and marshes and concludes with the allochthonous (clastic) travertines.

In Northern Euboea and Eastern Central Greece many hot springs exists and in some of them thermogenic travertines are depositing (Edipsos, Ilia, Thermopylae; Figure 1). Thermogenic travertine deposits near to the hot springs, where the hot water cools, degasses and rapidly precipitates calcium carbonate, creating different depositional facies-lithotypes having different crystal forms (Kanellopoulos, 2011; 2012) and many different morphological types.

The aim of this paper is to identify and describe the various morphological types of thermogenic travertine deposits in Northern Euboea and Eastern Central Greece. A further aim of this paper is to study their main mineralogical phases and to identify indications of possible organic controls on carbonate precipitation, in addition to the inorganic ones.

\section{Geological Setting}

North-western part of Euboea Island and Eastern Central Greece belongs geologically to the western part of the geotectonic units of the internal units of Greece, more specifically the Pelagonian and Sub-Pelagonian units (Aubouin, 1959; Mountrakis, 1986). The study area consists of various rock formations non-metamorphic rocks, ophiolitic rocks and metamorphic rocks. Large parts of NW Euboea and eastern central Greece are covered by Post Alpine Formations, Quaternary and Neogene age sediments (Figure 1). In the center of northern Euboea gulf the volcanogenic islands of Lichades are located (Georgalas, 1938). They are made mainly of trachyandesite lava flows, dated at $0.5 \mathrm{Ma}$ (Pe-Piper and Piper, 2002). The whole area is highly faulted due to extensional tectonics (McKenzie, 1970; 1972; Le Pichon and Angelier, 1979; Vavassis, 2001). Also, in the studied area many hot springs exist (Gioni-Stavropoulou, 1983), as a

XLVII, No 3 - 1930 
part of an active hydrothermal system, which present high concentrations to a large group of major and trace elements (Kanellopoulos, 2006; 2011).

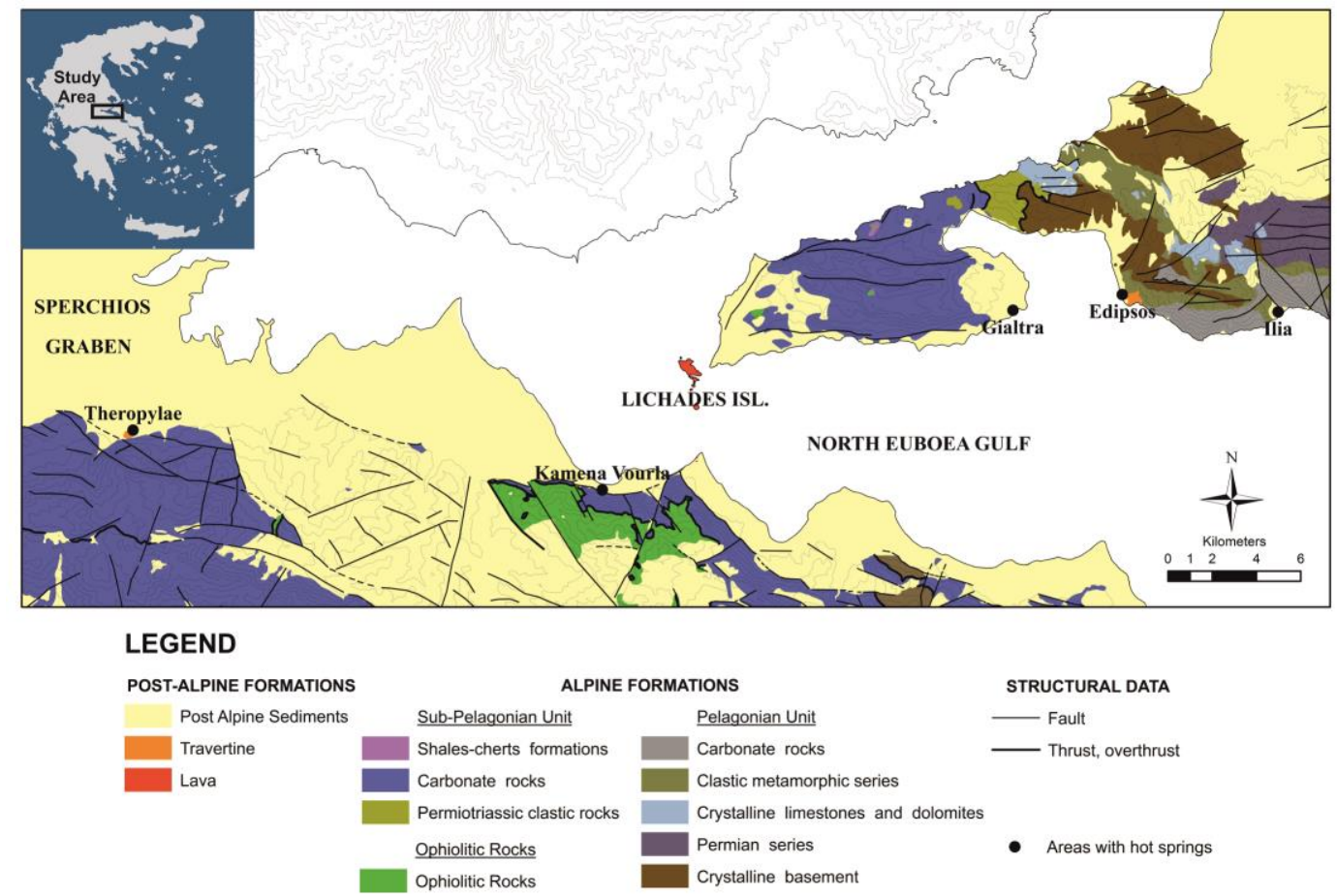

Figure 1 - Geological map of the study area (from Kanellopoulos, 2012).

\section{Materials and Methods}

All samples were studied at the laboratories of the Department of Geology and Geoenvironment, University of Athens. The mineralogical composition was investigated mainly by optical microscopy and X-Ray Diffraction. XRD analyses were carried out using a Siemens Model 5005 X-ray Diffractometer, $\mathrm{Cu}$ Ka radiation at $40 \mathrm{kV}, 40 \mathrm{nA}, 0.020^{\circ}$ step size and $1.0 \mathrm{~s}$ step time. The XRD patterns were evaluated using the EVA v.10.0 program of the Siemens DIFFRACplus and the D5005 software package. Scanning Electron Microscopy (SEM) and Energy Dispersive Spectroscopy (EDS) analyses were carried out using a Jeol JSM 5600 SEM instrument, equipped with an Oxford ISIS 300 OXFORD, with the following operating conditions: accelerating voltage $20 \mathrm{kV}$, beam current $0.5 \mathrm{nA}$, time of measurement $50 \mathrm{sec}$ and beam diameter 1-2 $\mu \mathrm{m}$. The spectra were processed using the ZAF program (3interaction). The microprobe analyses were conducted on polished sections of the samples after carbon coating.

\section{Location and Lithotype Description of Studied Travertine Deposits}

In the studied area, newly and older formed thermogenic travertine deposits occur in three different areas: Edipsos, Ilia and Thermopylae (Figure 1). In these areas the travertine deposits are thermogenic, created by the local hot springs. By the term older travertines, we mean all the travertines that have been created in the past; and the precipitation process has ended. In Edipsos, large deposits of thermogenic travertine occur, presenting great variety of morphological types and lithotypes. The most common active lithotypes in Loutra of Edipsos are crystalline crusts, rafts, foam type, lamination and spicular types (Kanellopoulos, 2012). Their color varies from whiteyellow to red, with orange prevailing. The hot springs in Edipsos exist from historical times and for that reason many ancient structures, such as Roman baths can be found. The deposition rate is 
high and in this area hot springs are self-settled in a short time with the depositing material and new springs arising nearby. The high rate of deposition creates problems for the exploitation of hot springs for spa therapy, as in a short period of time it results in the clogging of pipes used for the transfer of the hot water. Ilia area is located $7 \mathrm{~km}$ east of Edipsos. The travertine deposit in Ilia covers a small area $\left(\sim 2 \mathrm{~m}^{2}\right)$ and is created at the point where the pipe from the borehole vents out the hot water. At that position a reddish brown cascade has been created which consists of newly formed Fe-rich laminated travertine (Kanellopoulos, 2011). This travertine has Fe-rich parts, which sometimes appear as metallic zone layers creating botryoid structures. In Thermopylae, extensive deposits of thermogenic travertine occur. Their color varies from white to grey. During the field survey, we discovered newly formed travertine deposits and old ones, since the hot springs in the area exist from historical times. Works for the construction of a new National highway road as well as other supporting works were carried out in this area and many of these works have destroyed travertine deposits by digging and mixed them (Figure 2A).

\section{Results}

\subsection{Mineralogical Study and Chemical Composition of Main Mineral Phases}

The main mineral phases identified by XRD and SEM micro-probe analysis are aragonite and calcite, which in many cases coexist. In the Edipsos samples the predominant phase is aragonite. Its crystals tend to create hexagonal prisms, which at many times appear as radial spheres, while calcite usually creates rhombohedral crystals. In Ilia iron-rich travertine deposit, in addition to calcium carbonate mineral phases, an amorphous hydrous ferric oxyhydroxide phase was found (Table 1, anal. 9-10), identified as amorphous ferrihydrite (Kanellopoulos, 2011; 2012). In Thermopylae samples, only calcite was identified as the main mineral phase.

The chemical composition of calcium carbonate minerals varies (Table 1). The calcium carbonate mineral phases from Edipsos (Table 1, anal. 1-3) in addition to $\mathrm{Ca}, \mathrm{C}$, and $\mathrm{O}$, contain $\mathrm{S}$ and/or $\mathrm{Si}$ and/or $\mathrm{Na}$ and/or $\mathrm{Cl}$ and/or Fe, the travertines from Ilia (Table 1, anal. 4-6) in addition to Ca, $\mathrm{C}$, and $\mathrm{O}$, contain $\mathrm{Fe}$ and/or $\mathrm{As}$ and/or $\mathrm{Si}$ and/or $\mathrm{S}$ and/or $\mathrm{Sr}$ and/or $\mathrm{Na}$ and/or $\mathrm{Cl}$ and the travertines from Thermopylae (Table 1, anal. 7-8) in addition to $\mathrm{Ca}, \mathrm{C}$, and $\mathrm{O}$, contain $\mathrm{Mg}$ and/or $\mathrm{S}$.

Table 1 - Microanalysis of Aragonite - Calcite and Ferrihydrite (in compound \%).

\begin{tabular}{ccccccccc}
\hline & \multicolumn{7}{c}{ Aragonite and Calcite } \\
& $\mathbf{1}$ & $\mathbf{2}$ & $\mathbf{3}$ & $\mathbf{4}$ & $\mathbf{5}$ & $\mathbf{6}$ & $\mathbf{7}$ & $\mathbf{8}$ \\
\hline $\mathbf{S i O}_{2}$ & - & - & 0.34 & 3.66 & 1.75 & 0.58 & - & - \\
$\mathbf{F e O}$ & - & - & 0.35 & 12.99 & 7.98 & 0.60 & - & - \\
$\mathbf{C a O}$ & 47.57 & 49.45 & 48.17 & 38.35 & 44.35 & 47.71 & 47.80 & 47.53 \\
$\mathbf{N a 2 O}$ & - & - & 0.73 & - & - & 0.55 & - & - \\
$\mathbf{A s 2} \mathbf{O}_{3}$ & - & - & - & 0.53 & 0.54 & - & - & - \\
$\mathbf{M g O}$ & - & - & - & - & - & - & 1.43 & 1.75 \\
$\mathbf{S O}$ & - & 0.40 & 3.70 & 0.82 & - & - & - & 0.87 \\
$\mathbf{S r O}$ & - & - & - & - & - & 1.05 & - & - \\
$\mathbf{C l}$ & - & 0.18 & - & - & 0.10 & - & - & - \\
$\mathbf{T o t a l}$ & 47.57 & 50.03 & 53.29 & 56.36 & 54.73 & 50.50 & 49.23 & 50.15 \\
& & & & & & & & \\
$\mathbf{A t o m s}$ & $\mathbf{2}$ & $\mathbf{2}$ & $\mathbf{2}$ & $\mathbf{2}$ & $\mathbf{2}$ & $\mathbf{2}$ & $\mathbf{2}$ & $\mathbf{2}$ \\
$\mathbf{S i}$ & - & - & 0.0064 & 0.0649 & 0.0321 & 0.0114 & - & - \\
$\mathbf{F e}$ & - & - & 0.013 & 0.4611 & 0.2915 & 0.0239 & - & - \\
$\mathbf{C a}$ & 2 & 1.9768 & 1.8081 & 1.3611 & 1.6210 & 1.8896 & 1.9201 & 1.8955 \\
$\mathbf{N a}$ & - & - & 0.0546 & - & - & 0.0438 & - & - \\
$\mathbf{A s}$ & - & - & - & 0.0125 & 0.0132 & - & - & - \\
$\mathbf{M g}$ & - & - & - & - & - & - & 0.0799 & 0.0698 \\
$\mathbf{S}$ & - & 0.0053 & 0.0462 & 0.0097 & - & - & - & 0.0116 \\
$\mathbf{S r}$ & - & - & - & - & - & 0.0417 & - & - \\
$\mathbf{C l}$ & - & 0.0072 & - & - & 0.0037 & - & - & - \\
\hline
\end{tabular}

\begin{tabular}{ccc}
\hline & \multicolumn{2}{c}{ Ferrihydrite } \\
& $\mathbf{9}$ & $\mathbf{1 0}$ \\
\hline $\mathbf{S i}$ & 6.37 & 4.67 \\
$\mathbf{F e}$ & 38.34 & 39.49 \\
$\mathbf{C a}$ & 3.12 & 1.6 \\
$\mathbf{A s}$ & 2.92 & 5.19 \\
Total & 50.75 & 50.95 \\
& & \\
Atoms & $\mathbf{2}$ & $\mathbf{2}$ \\
$\mathbf{S i}$ & 0.1915 & 0.1429 \\
$\mathbf{F e}$ & 1.3861 & 1.4539 \\
$\mathbf{C a}$ & 0.1227 & 0.0641 \\
$\mathbf{A s}$ & 0.0722 & 0.1307 \\
\hline
\end{tabular}

$\underline{\text { XLVII, No } 3-1932}$ 


\subsection{Morphological Types}

In the studied areas, eleven morphological types of travertine were identified. All of them were thermogenic, mostly autochthonous created by the local hot springs. Some types are quite common, while some others are rare, (e.g. cascades, remoras). The main morphological types of the studied travertines are:

I) Spring mounds are domes of travertine, in surrounding of a spring orifice. Most mounds require hydrostatic head and the orifice shape determine their solid geometry. In the studied area two mound types were identified: mounds with wide orifices and smooth walls containing pools of water (Figure 2B) and some low mounds, usually their height is less than $15 \mathrm{~cm}$. The low mounds are of low relief with a dip of just a few degrees. In these cases, the mound outlines become irregular, presumably in response to minor differences in ground level surrounding the springs (Figure 2K). In Edipsos, the orifices of mounds frequently self-seal due to the rapid deposition and maybe the short operating time is one of the major reasons for not having high mounds types. The formation of mounds is not understood in detail but it is clear that most of them require water under pressure, like Edipsos (Figure 2C). The hydrostatic pressure needed to form the largest mounds is considerable, approaching $7 \mathrm{~kg} / \mathrm{cm}$ at ground level (Pentecost, 2005). These pressures exist in artesian systems and most mounds probably develop in this way, but geyser-like activity may be responsible on mound height must be limited by the hydrostatic head and the rate of flow presumably falls as the mound builds. Kerr and Turner (1996) have shown that the overflow of water at a mound orifice is controlled by surface-tension effects. The orifice necks of old mounds in Edipsos are often smooth and symmetrical. The high degree of supersaturation lead to rapid deposition around the vent giving a steep mound, while waters closer to saturation are likely to deposit at increasing distances, providing a more modest profile under conditions of equal discharge.

II) At active travertine sites two types of cascade can be distinguished: the erosively-shaped deposits, approximately parabolic in section and frequently with fluted channels, with morphology which is largely controlled by stream direction, and the accretionary deposits, irregular and regular deposition in which the deposition rate is bigger than the erosion rate over long periods (Pentecost, 2005). Accretionary types are typical of high-discharge streams with vertical falls formed along resistant rock layers (Dennen et al., 1990). Thermogene travertines forming on hillsides and cliffs often develop this type. In these cases, lateral extension is restricted only by the mechanical strength of the travertine. In Edipsos accretionary, mainly keeled cascade and remora types were identified. Throughout the city of Edipsos, near the hot springs, narrow channels have been constructed. Their purpose is to collect the hot water from the residential area and drive it away. Usually the end of these channels is a slot at the top of a cliff. Water overtops the slot and seeps down slope, depositing travertine in the process, building up the sides of the keel, slowly raising the height (Figure 2D). Deposition ceases soon after the water flows down the wall, otherwise, the walls extend outwards and lose their almost vertical form. In Edipsos, many active and non-active cascades were identified. Usually, active cascades have rich flora (boggy hollows, cyanobacteria, Figure 2E). Cascades which were formed near the sea level have cave forms at their bases. Probably the erosion at the base of these cascades is significantly higher due to sea waves, which are reaching the cascade base. These morphological types were also identified in Ilia and Thermopylae. In Ilia at the point where the pipe from the borehole vents out the hot water, a small cascade has been created. In Thermopylae, cascade type was identified at the point where the channel of hot water ends, creating a hot water waterfall (Figure 2F). Remora types develop in slow or intermittent water flow over steep slopes (older cascades or cement walls) and consist of stalactite-like masses often of gravity-defying forms (Figure $2 \mathrm{G}$ ).

III) Dams (barrage) distinguished from cascades by their localized vertical accretion leading to water impoundment as pools (terraces, Figures $2 \mathrm{H}, \mathrm{I})$. Dams usually occur in series along watercourses. In Edipsos their height ranges from millimeters to few centimeters and the distance between them ranges from few centimeters to few meters, probably depending on the gradient of

$\underline{\text { XLVII, No } 3-1933}$ 
the stream bed and the discharge. Each dam is separated by a pool and their depth usually is up to few $\mathrm{cm}(<5 \mathrm{~cm})$. The dams themselves are composed of travertine formed in situ. In Thermopylae dams' height ranges from millimeters to 1 centimeter.

IV) Fluvial crusts include a range of superficial deposits formed in the running water of small and large streams (Figure 2J). They develop on a variety of structures which are either smooth, or nodular and coralloid. Detached crusts, called oncoids develop around stones and plant nuclei. In Edipsos and Ilia many laminated oncoids develop around bedrock stones, old compact travertine fragments and plant nuclei (Figure 2J). Also, in Edipsos travertine crusts usually grade into lowrelief mounds around spring orifices, forming sheets over the bedrock. In Thermopylae usually laminated smooth surfaces were developed around bedrock.

V) Lake deposits (Terraces) are pools with small depth and low flow velocity. They are part of the fluvial system, the slow passage of water through lakes means that $\mathrm{CO}_{2}$ evasion is reduced, while photosynthesis and evaporation become increasingly important as progenitors of carbonate precipitation. They are very common in Edipsos (Figure 2K). Over the rim and on the steep outside wall of the terrace (dam), water flows in a thin sheet and flow velocity increases. Morphological classification schemes for travertine terrace have been proposed by several authors (Bargar, 1978; Bates and Jackson, 1987; Pentecost and Viles, 1994; Fouke et al., 2000;). Using the classification suggested by Bargar (1978) and Fouke et al. (2000) in Edipsos "terracettes" i.e. areas of a few square meters and "microterracettes" of a few square centimeters or less, were identified. Hammer et al. (2010) suggested the term "terrace" as a general term regardless of size. In Edipsos the height of terracettes (dam) and microterracettes is up to few centimeters, regardless of slope, thus producing pools of much larger area in regions of small slope. It is commonly observed at terrace systems which are partly dry. This is not always due to primarily reduction in overall flux. As a result of travertine build-up, water continuously finds new routes. Old pathways may be abandoned and dry up, but become active again at a later date (Chafetz and Folk, 1984; Hammer et al., 2010). Inside Edipsos pools of many different lithotypes are being created, like rafts, foam, shrubs etc (Kanellopoulos, 2012).

VI) Reefs are small morphological types (millimeters to few centimeters in size) found attached to sediments or rock walls at terraces and stream margins (Figure 2L). In Edipsos, reefs at stream margins usually create spicular lithotypes. Their origin is unclear, probably they are some form of agglutination process, possibly related with microbial mediated occur (Thompson and Ferris, 1990). These deposits although resembling travertine, may not be primarily the result of degassing and need further investigation (Pentecost, 2005).

VII) Paludal deposits are low-relief accumulations often including much carbonate mud. They are found in marsh environments with slow-flowing water and much vegetation. Edipsos` paludal deposits are probably associated with sulfur- and cyano-bacteria based on field observations. At these sites grass and moss cushions can be found (Figure $2 \mathrm{M}$ ).

VIII) Cemented clasts consist of cemented scree, alluvium, breccia, and gravel formed as a result of ground and surface water degassing to the epigean atmosphere, but it is not always possible to distinguish between near-surface and hypogeal cementation, the latter resulting from precipitation from calcite supersaturated ground waters. In Edipsos grains are from fine sand and silt (10-120 $\mu \mathrm{m})$ (Figure $2 \mathrm{~N}$ ) to large clasts (few centimeters). They are cemented by $\mathrm{CaCO}_{3}$ and they are usually highly resistant to erosion and very hard. In Ilia, travertine deposits on a beach. It is usual inside the travertine to be found cemented grain (up to few centimeters) from the beach.

IX) Allochthonous (Clastic) travertines are forming in turbulent environments. Travertines soon after formation they often undergo erosion, so many deposits contain a significant proportion of clastic material (Garcia del Cura et al., 2000). Travertine-marls forming in paludal environments are especially prone to re-deposition and a range of predominantly clastic deposits have been distinguished in the studied area, especially in natural streams at the outskirts of Loutra of Edipsos city and in Thermopylae.

$\mathbf{X})$ In Edipsos, travertine caves are frequently exist beneath cascades near seashore. These develop either as the travertine builds a protuberance over a steep cliff which eventually meets the ground

$\underline{\text { XLVII, No } 3-1934}$ 

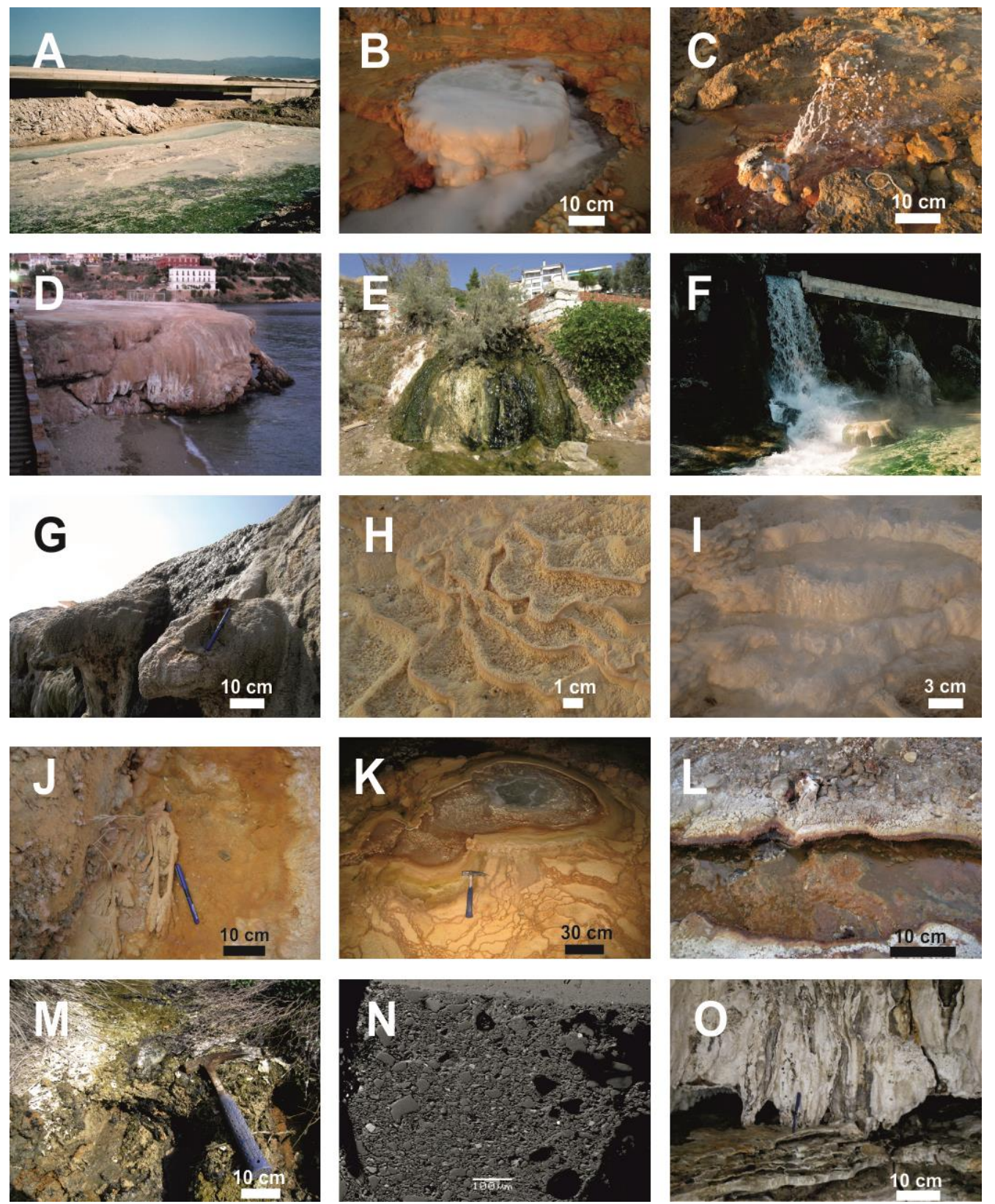

Figure - 2. Morphological types of studied travertines. (A) Works in Thermopylae, which have destroyed the travertine morphological types. (B) Steep-smooth spring mound in Edipsos. (C) Hot spring with high hydrostatic pressure, proving that Edipsos hot springs are artesian systems. (D) Active cascades with rich flora (boggy hollows, cyanobacteria) in Edipsos seashore. (E) Hot water waterfall in Thermopylae creating cascade (existence of cyanobacteria). (F) Large non-active now cascade formation in Edipsos, at the base of the cascade travertine caves can be distinguished. (G) Remora type, in Edipsos, developed on a large cascade, at the seashore, only few meters $(2 \mathrm{~m})$ above sea level. (H) Dams (barrage) part of a dry terrace system in Edipsos. (I) Dams (barrage) part of an active terrace system in Edipsos. (J) Fluvial crusts in a dry stream (Edipsos). The crusts covered the old travertines (bedrock) and in the left side can be distinguish fluvial crust developed using plants as nuclei. (K) Spring mound with pools (terraces system) creating low mounds in Edipsos. (L) 
Reefs with spicular lithotypes attached to stream margins, in Edipsos. (M) Paludal deposits in marsh environment (associated with sulfur- and cyano-bacteria, in Edipsos). (N) Cemented clasts in Edipsos (Fe oxides, Ti oxides, quartz and apatite). (O) Speleothems from an Edipsos travertine cave on the base of a cascade.

leaving a cavity behind it or as a result of the significantly higher erosion at the base of these cascades due to sea waves, which are reaching the cascade base (Figure 2D). Usually they are located near the sea level at the base of cascades and they have small dimensions e.g. height usually less than $1 \mathrm{~m}$.

XI) Speleothems are morphological types formed in caves. Hill and Forti (1997) provide a good overview of these forms and recognize five hydrological mechanisms responsible for most of the variation: dripping, flowing, seeping, pooled and splashing water. Other processes such as evaporation, airflow, and joint geometry account for much of the remaining variation. In Edipsos straws, stalactites, stalagmites (some joined into columns) and flowstones with lamination forms were identified (Figure 2O). Based on field observations (e.g. cyanobacteria growths), possible inorganic and organic controls on carbonate precipitation in these sites are suggested.

\section{Discussion-Conclousions}

In this study, Northern Euboea and Eastern Central Greece travertines (Edipsos, Ilia and Thermopylae), were examined and a large variety of morphological types were identified and described. Edipsos and Thermopylae are probably the biggest active travertine-forming systems in Greece, while Ilia is a smaller one. Also some of the data recorded during this study suggest possible organic controls on carbonate precipitation in the studied hot springs. The studied travertine deposits are composed of two calcium carbonate polymorphs (i.e. aragonite and calcite), which, in many cases were found to coexist. Aragonite tends to create hexagonal prisms, which many times appear as radial spheres or fan-shaped radiating needles, while calcite usually creates rhombohedral crystals.

From the mineralogical study it was found that the predominant phase of the travertines in Euboea was aragonite, while Thermopylae travertines have only calcite. The exact conditions that favor aragonite precipitation at one time and calcite at another are unclear. Kanellopoulos (2012) suggests that most important factors favoring the dominant creation of aragonite in Euboea travertines and calcite in Thermopylae travertines are temperature and Sr content of the hot springs. In Thermopylae hot springs the temperatures $\left(33-40{ }^{\circ} \mathrm{C}\right.$ ) are lower compared to Euboea hot springs (43-82 ${ }^{\circ} \mathrm{C}$ ). The formation of aragonite from high-temperature waters is suggested by many studies (Sturchio, 1990; Folk, 1994; Fouke et al., 2000). Folk (1994) observed that if the water temperature is above $40{ }^{\circ} \mathrm{C}$, aragonite would precipitate, regardless of the fluid composition and calcite would form if the water is rich in $\mathrm{Ca}$ and cooler than $40{ }^{\circ} \mathrm{C}$. Fouke et al. (2000) also showed that if the water temperature is above $44{ }^{\circ} \mathrm{C}$, aragonite forms. The $\mathrm{Sr}$ content in Thermopylae hydrothermal fluid $(11900 \mu \mathrm{g} / \mathrm{L})$ and travertines $(2160 \mathrm{mg} / \mathrm{kg})$ is lower compared to Edipsos hydrothermal fluid (up to $17400 \mu \mathrm{g} / \mathrm{L}$ ) and travertines (up to $3960 \mathrm{mg} / \mathrm{kg}$ ) and to Ilia hydrothermal fluid (up to 29900 $\mu \mathrm{g} / \mathrm{L}$ ) and travertines (up to $4260 \mathrm{mg} / \mathrm{kg}$ ) (Kanellopoulos, 2011). Similar cases (i.e. low content of Sr-creation of calcite) have been presented by many studies. Ishigami and Suzuki (1977) point out a strong positive correlation between $\mathrm{Sr}$ content and the proportion of aragonite in Japanese travertines. Malesani and Vannucchi (1975) suggest that a high level of Sr in hydrothermal fluid favors the deposition of aragonite. The travertine deposits developed in hot springs with a high concentration of iron (e.g. Ilia), containing an amorphous hydrous ferric oxyhydroxide mineral phase $\left(5 \mathrm{Fe}_{2} \mathrm{O}_{3} * 9 \mathrm{H}_{2} \mathrm{O}\right.$; Kanellopoulos, 2012), which, along with aragonite, are the main mineral phases.

The chemical composition of calcium carbonate mineral phases varies from area to area, depending on the chemical composition of the hydrothermal fluid (Kanellopoulos, 2011). So, the calcium carbonate mineral phases from Edipsos in addition to $\mathrm{Ca}, \mathrm{C}$, and $\mathrm{O}$, contain $\mathrm{S}$ and/or $\mathrm{Si}$ and/or $\mathrm{Na}$ and/or $\mathrm{Cl}$ and/or $\mathrm{Fe}$, the travertines from Ilia, in addition to $\mathrm{Ca}, \mathrm{C}$, and $\mathrm{O}$, contain $\mathrm{Fe}$

$\underline{\text { XLVII, No } 3-1936}$ 
and/or As and/or Si and/or S and/or $\mathrm{Sr}$ and/or $\mathrm{Na}$ and/or $\mathrm{Cl}$ and the travertines from Thermopylae, in addition to $\mathrm{Ca}, \mathrm{C}$, and $\mathrm{O}$, contain $\mathrm{Mg}$ and/or $\mathrm{S}$ (Table 1). Previous studies at the same travertines (Kanellopoulos, 2011) prove that except from the calcium carbonate minerals other mineral phases were present, usually in the form of very small crystals, which are located within the pores of the travertine deposits.

In the present study the major morphological types of Northern Euboea and Eastern central Greece thermogenic travertine deposits were identified, characterized and described. Almost all the morphological types of thermogenic travertines, that the classification of Pentecost and Viles (1994) propose, were identified. More specifically, in the studied areas, eleven main morphological types of thermogenic travertine were found. Some of them are common (i.e. fluvial crust), while some others are rare ones (i.e. cascades, remoras, caves). The co-existence of all these morphological types in one area is not usual. Also, in the same area Kanellopoulos (2012) identified and described a great variety of lithotypes. Signs of biological processes were detected (growths of cyanobacteria and/or algae in the travertines), suggesting possible inorganic and organic controls on carbonate precipitation in the studied systems. All these make the Northern Euboea and Eastern central Greece active travertine systems of quite important and create questions for further research, in order to determine the controlling factors that favor the deposition of each type.

\section{Acknowledgments}

The author would like to thank Prof. P. Mitropoulos for his encourage and support in this research.

\section{References}

Aubouin J. 1959. Contribution a l'étude géologique `de la Grèce septentrionale: Les confins de l'Epire et de la Thessalie, Ann. Géol. Pays Hellen, 10, 1-483.

Bargar K.E. 1978. Geology and thermal history of Mammoth Hot Springs, Yellowstone National Park, Wyoming, U.S. Geol. Surv. Bull., 1444, 1-55.

Bates R.L. and Jackson J.A. 1987. Glossary of Geology, 3rd Ed., Alexandria, Va. (American Geological Institute).

Chafetz H.S. and Folk R.L. 1984. Travertines: depositional morphology and the bacterially constructed constituents, J. Sed. Petrol., 54, 289-316.

Dennen K.O., Diecchio R.J. and Stephenson M.A. 1990. The geology of the Falling Spring travertine deposit, Alleghany Co., Virginia, 79-92, in: J.S. Herman, D.A. Hubbard (eds), Travertine-marl: Stream Deposits in Virginia. Virginia Division of Mineral Resources Publication 101, Charlottesville, Va (Virginia Division of Mineral Resources).

Folk R.L. 1994. Interaction between bacteria, nannobacteria and mineral precipitation in hot springs of Central Italy, Geogr. Phys. Quaternaire, 1994, 48, 233-246.

Fouke B.W., Farmer J.D., Des Marais D.D., Pratt L., Sturchio N.C., Burns P.C. and Discipulo M.K. 2000. Depositional facies and aqueous-solid geochemistry of travertine-depositing hot springs (Angel Terrace, Mammoth Hot Springs, Yellowstone National Park, U.S.A.), Journal of Sedimentary Research, 70, 565-585.

Garcia del Cura M.A., Pedley H.M., Ordopez S. and Gonzalez Martin J.A. 2000. Petrology of a barrage tufa system (Pleistocene to Recent) in the Ruidera Lakes Natural Park (Central Spain), Geotemas, 1, 359-363.

Georgalas G.C. 1938. Le volcans des 1^les Likhades et de Hagios Ioannis (Kammena Vourla), Praktika Academia Athinion, 13, 86-98.

Gioni-Stavropoulou G. 1983. Inventory of hot and mineral springs of Greece, I, Aegean sea, $H y$ drological and Hydrogeological Investigation Report, No. 39, IGME, Athens (in Greek).

Glover C. and Roberston A.F.H. 2003. Origin of tufa (cool water carbonate) and related terraces in the Antalya area, SW Turkey, Geol. J., 38, 329-358. 
Hammer Ø, Dysthe D. K. and Jamtveit B. 2010. Travertine terracing: patterns and mechanisms, Geological Society Special Publication, 336, 345- 355.

Hill C.A. and Forti P. 1997. Cave Minerals of the World. 2nd Edn., 463 pp., Alabama (National Speleological Society).

Ishigami T. and Suzuki R. 1977. Factors affecting the crystalline form of calcareous sinters, Geochemistry, Tokyo.

Kanellopoulos C. 2006. Geochemical research on the distribution of metallic and other elements to the groundwater in Fthiotida Prefecture and Northern Euboea, Master Thesis, University of Athens, Greece (in Greek).

Kanellopoulos C. 2011. Geochemical research on the distribution of metallic and other elements to the cold and thermal grondwater, soils and plants in Fthiotida Prefecture and N. Euboea. Environmental impact, Ph.D. Thesis, University of Athens, Greece (in Greek).

Kanellopoulos C. 2012. Distribution, lithotypes and mineralogical study of newly formed thermogenic travertines in Northern Euboea and Eastern Central Greece, Central European Geosciences, 4(4), 545-560.

Kerr R.C. and Turner J.S. 1996. Crystallization and gravitationally controlled ponding during the formation of mound springs, terraces, and "black smoker" flanges, J. Geophys. Res., 101, 25125-25137.

Koban C.G. and Schweigert G. 1993. Microbial origin of travertine fabrics- two examples from Southern Germany, Facies, 29, 251-264.

Le Pichon X. and Angelier J. 1979. The Hellenic Arc and Trench system: A key to the neotectonic evolution of the Eastern Mediterranean area, Tectonophysics, 60, 1-42.

Malesani P. and Vanucchi S. 1975. Precipitazione di calcite di aragonite dalle acque termominerali in relazione alla genesi e all'evoluzione dei travertine, Accademia Lincell, Rendiconti Scienze fisica, matematica e natural, 58, 761-776.

McKenzie D. 1970. Plate Tectonics of the Mediterranean Region, Nature, 226, 239-242.

McKenzie D. 1972. Active tectonics of the Alpide - Himalayan belt: the Aegean Sea and surrounding regions (Tectonics of the Aegean Region), Geophys. J.Roy. Astr. Soc., 55, $217-$ 254.

Mitchell R.S. 1985. Dictionary of Rocks, New York (Van Nostrand).

Mountrakis D. 1986. The Pelagonian zone in Greece: A polyphase deformed fragment of the Cimmerian continent and its role in the geotectonic evolution of the Eastern Mediterranean, Journal of Geology, 94, 335 - 347.

Ordopez S., Gonzalez J.A. and Garcia del Cura M.A. 1986. Pitrographie et morphologie des idifices tuffeux quaternaires du centre de l'Espagne, Mediterranie, 1-2, 52-60.

Pentecost A. and Viles H. 1994. A review and reassessment of travertine classification, Geographie physique et Quatemaire, 48, 3, p. 305-314.

Pentecost A. 2005. Travertine, Springer-Verlag.

Pe-Piper G.and Piper D. 2002. The igneous rocks of Greece, the anatomy of an orogen, (Gebruder Borntraeger), Berlin.

Riding R. 1991. Classification of microbial carbonates, In: R. Riding (Ed.), Calcareous Algae and Stromatolites, Berlin (Springer-Verlag), 21-51.

Scheuer G. and Schweitzer F. 1989. Genetics and occurrence of Holocene travertines in Hungary. Studies in Geography in Hungary, Akademici Kiado, 25, 39-48, Budapest.

Sturchio N.C. 1990. Radium isotopes, alkaline earth diagenesis, and age determination of travertine of Mammoth Hot Springs, Wyoming, U.S.A., Appl. Geochem., 5, 631-640.

Thompson J.B. and Ferris F.G. 1990. Cyanobacterial precipitation of gypsum, calcite and magnesite from natural alkaline lake water, Geology, 18, 995-998.

Vavassis I. 2001. Geology of the Pelagonian zone in Northern Evia Island (Greece): Implications for the geodynamic evolution of the Hellenides, These de doctorat, Univ. de Lausanne.

Viles H.A. and Goudie A.S. 1990. Reconnaisance studies of the tufa deposits of the Napier Range, N.W. Australia, Earth Surf. Proc. Landf., 15, 425-443.

Whitten D.A. and Brooks J.V.R. 1972. The Penguin Dictionary of Geology, London (Penguin).

$\underline{\text { XLVII, No } 3-1938}$ 